\title{
Response of African Giant Land Snail (Archachatina marginata) to Graded Levels of Asplenium barteri Leaf Meal Supplement
}

\author{
P.C.N Alikwe, M, Okpeku and S. Ndukari \\ Animal Science Department, Faculty of Agriculture, Niger Delta University, Wilberforce Island, Bayelsa State
}

\begin{abstract}
The effect of feeding graded level (0, 5, 10 and 15\%) of Aspelenium barteri Fern leaf meal supplement to growing Archachatina marginata on growth indices, organ weight and carcass characteristics was investigated. One hundred and twenty (120) growing snails (Archachatina marginata) were randomly allocated to four treatments of 30 snails each, replicated three times with 10 snails per replicate in a completely randomized design. The experiment lasted for six (6) weeks. In this study Carcass weight, gut content, feed intake, body weight, shell length/width and FCR differed significantly $(P<0.05)$ whereas live weight, shell weight, meat content, foot length and foot thickness were not significantly different $(P>0.05)$ among treatment diets. Diet with $15 \%$ inclusion of FLM was considered suitable for best performance.
\end{abstract}

Key words: body weight, carcass, fern leaf, growth, shell weight,

\section{Introduction}

African giant snail (Archachatina marginata) is one of the most important minor forest products in West Africa and Nigeria in particular. Snail production serves as cheap source of animal protein supply. The meat has a high protein content of about $83-93 \%$ (Imevbore and Ademosum, 1988), making it compare favourably with other conventional protein sources. Archachatina marginata eat a wide range of feed but prefer herbs and vegetables; they compete with man for his available vegetable. To prevent unwholesome competition, non-conventional alternate sources of rich feed for snails are and other livestock have become subject of scientific research in recent times (Karsin et al 2008; Obun and Ayanwale, 2008; Egena et al 2008, Asiegwe et al 2008 and Tuleum et al 2010). Benefits of using aquatic plants (ferns, duckweed and water hyacinth) as source of protein in animal production with low cost have been demonstrated (Maricel et al 1999; Camus et al 1991). The present study was undertaken to determine the response of African Giant land snails to graded levels of fern (Asplenium barteri) leaf meal supplement

\section{Materials And Methods}

LOCATION AND DURATION OF STUDY

The experiment was carried out at the Teaching and Research Farm of the Faculty of Agriculture in Niger Delta University, Wilberforce Island, Amassoma, Bayelsa State. The study lasted for six (6) weeks.

\section{EXPERIMENTAL SNAILS AND DESIGN}

A total of 135 juvenile snails were randomly assigned to four treatment groups in 3 replicates with 10 snails per replicate in a completely randomized design (CRD).

\section{EXPERIMENTAL DIET}

Graded levels of fern leave meal (FLM) was used as a substitute for protein at the rate of $0 \%, 5 \%, 10 \%$ and $15 \%$ in the dietary treatments and designated $\mathrm{T} 1, \mathrm{~T} 2, \mathrm{~T} 3$ and $\mathrm{T} 4$ respectively. T1 ( $0 \%$ FLM) served as the control diet. The FLM was meticulously mixed with other feed ingredients in a formulated ration as shown in Table 1

\begin{tabular}{lllll}
\multicolumn{1}{c}{ Table 1 } & The formulated diet for snail & & T3 & \\
\hline Ingredient (0\%) & T1 & T2 & 26. & 24.00 \\
Maize & 31.00 & 29.00 & 14.00 & 13.00 \\
Wheat offal & 16.00 & 15.00 & 24.00 & 25.00 \\
Soya beans meal & 23.00 & 22.00 & 10.00 & 7.00 \\
Groundnut cake & 10.00 & 7.00 & 3.25 & 3.25 \\
Fish meal & 6.25 & 6.25 & 4.25 & 4.25 \\
Palm kernel cake & 4.25 & 4.25 & 6.75 & 6.75 \\
Oyster shell & 7.75 & 9.75 & 1.5 & 1.5 \\
Bone meal & 1.5 & 1.5 & 0.25 & 0.25 \\
Premix/vitamin/mineral & O.25 & 0.25 & 10.00 & 15.00 \\
Fern & 0.0 & 5.00 & 100.00 & 100.00 \\
TOTAL (100\%) & 100.00 & 100.00 & & \\
\hline GTMENT
\end{tabular}

MANAGEMENT OF EXPERIMENTAL SNAILS 
A cage with rectangular wooden frames and a plywood cover and wire mesh covering the side was used. The bottom was covered with wire mesh and perforated polythene to allow free drainage of water. The snails were fed ad-libitum for 6 weeks. Measurement of the shell length increment and width was done using vernier caliper (to the nearest millimeter). The weight of snails was taken on a weekly basis by means of electric weighing balance measured in grams. At the end of the experiment, two of the snails were eviscerated from the shell. The eviscerated snail parts were weighed individually and recorded. Shell, carcass, meat content, and the gut content weighed separately. $30 \mathrm{~cm}$ ruler was used to measure the foot length and foot thickness while vernier caliper was used to measure the shell length and width of the snails.

\section{CHEMICAL ANALYSIS}

The proximate analysis. Showing nutrient profile of the FLM supplement and constituted diet profile of the fern (Asplenium barteri) and the experimental feeds (Table 2 and 3) were carried out according to the procedures described by A.O.A C (1995)

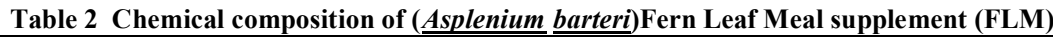

\begin{tabular}{ll}
\hline Constituent's & \% \\
\hline Moisture & 11.80 \\
Crude Protein $\quad$ fibre & 9.63 \\
Crude $\quad 14.84$ \\
Ether extract & 3.00 \\
Ash & 7.20 \\
NFE & 53.54 \\
Total & 100.00 \\
\hline
\end{tabular}

\begin{tabular}{lllll} 
& Table 3 & Chemical composition of the experimental diets & T3(\%) & T4(\%) \\
\hline Constituents & T1 (\%) & T2 (\%) & 16.20 & 19.00 \\
\hline Moisture & 14.00 & 14.00 & 15.63 & 18.16 \\
Crude Protein & 17.06 & 13.17 & 4.00 & 4.00 \\
Ether Extract & 11.00 & 7.00 & 9.85 & 11.83 \\
Crude fibre & 9.47 & 8.99 & 9.00 & 10.00 \\
Ash & 6.44 & 8.00 & 45.32 & 37.01 \\
NFE & 42.13 & 48.84 & 100.00 & 100.00 \\
Total & 100.00 & 100.00 & & \\
\hline
\end{tabular}

\section{STATISTICAL ANALYSIS}

The data obtained from all the parameters were subjected to statistical analysis. The analysis of variance was used according to the method of Steel and Torrie (1981), means that were significant were separated using Duncan's multiple Range Test (Duncan, 1995)

\section{Results And Discussion}

Proximate composition of the FLM and the proximate composition of the compounded experimental diet are shown in Table 2 and 3. A crude protein of $9.63 \%$ is relatively high and contrast well with crude protein reported in literature for feed stuffs (Sese et al 2013), Effect of the experimental diet on growth performance of African Giant Land snail is shown in Table 4 and 5. The values for each parameter for average feed intake, mean body weight, mean shell length and mean shell width were not very wide but differ significantly $(\mathrm{P}<0.05)$ with the control diet. Feed intake values were significant $(p<0.05)$ implying that the experimented feeds was accepted by the snails. Feed intake is subject to palatability and animals are known to eat more when feed is palatable and tasty. African Giant Land snails have been reported to be picky in their feed choices, preferring succulent leafy plants (Okpeku and Omueti, 2003). The significance in body weight is an indication that what was consumed was well utilized by the snails; this also was evident in significant values recorded for shell length and width. This supports the theory that African giant Land snails eat to increase the shell length and width to make room for growth of the internal mass (Hodasi, Awesu and Imevbore).Apart from gut weight, other parameters in Table 5 were not significant $(\mathrm{P}>0.05)$ indicating that the experimental snails responded equally to both the experimental and control diets. .Low percent mortality recoded only for snails in Diet T4 is an indicator that FLM supplemented feed for snails pose no threat to the well being of the snails. .

Table 4 Impact of FLM on Average feed intake, body weight, shell length shell width and feed conversion ratio.

\begin{tabular}{|c|c|c|c|c|c|c|}
\hline & $\mathrm{T} 1$ & $\mathrm{~T} 2$ & T3 & T4 & & Sig \\
\hline Parameters & Mean & Mean & Mean & Mean & SEM & \\
\hline Average feed intake (g/snail) & $7.06^{\mathrm{a}}$ & $6.60^{\mathrm{a}}$ & $5.27^{\mathrm{b}}$ & $5.04^{b}$ & 0.19 & $<0.05$ \\
\hline Mean body weight(g/snail) & $66.44^{\mathrm{a}}$ & $65.56^{\mathrm{a}}$ & $63.67^{\mathrm{b}}$ & $61.62^{c}$ & 0.66 & $<0.05$ \\
\hline Mean shell length (mm/snail) & $78.79^{\mathrm{a}}$ & $79.74^{\mathrm{a}}$ & $76.52^{\mathrm{b}}$ & $76.51^{\mathrm{b}}$ & 0.43 & $<0.05$ \\
\hline Mean shell width (mm/snail) & $45.09^{\mathrm{a}}$ & $44.69^{\mathrm{a}}$ & $42.43^{\mathrm{b}}$ & $43.29^{\mathrm{b}}$ & 0.36 & $<0.05$ \\
\hline Feed conversion ratio & $0.11^{\mathrm{a}}$ & $0.10^{\mathrm{a}}$ & $0.08^{\mathrm{b}}$ & $0.09^{\mathrm{b}}$ & 0.00 & $<0.05$ \\
\hline
\end{tabular}




\begin{tabular}{|c|c|c|c|c|c|c|}
\hline Mortality (\%) & & 0 & 0 & 0.03 & 0.00 & 0.07 \\
\hline \multicolumn{7}{|c|}{ Means with different superscripts in each row are significantly different $(\mathrm{p}<0.05)$. } \\
\hline Weight (g) & $\mathbf{T}_{1}$ & $\mathbf{T}_{2}$ & $\mathbf{T}_{3}$ & $\mathbf{T}_{4}$ & SEM & Sig \\
\hline Final Live weight $(\mathrm{g})$ & 147.00 & 148.66 & 155.33 & 158.66 & 10.79 & 0.08 \\
\hline \multicolumn{7}{|l|}{ Carcass } \\
\hline Shell weight (g) & 43.00 & $80.33^{\mathrm{a}}$ & $83.33^{\mathrm{a}}$ & $88.00^{\mathrm{a}}$ & 5.10 & $<0.05$ \\
\hline Visceral weight $(\mathrm{g})$ & $62.33^{\mathrm{b}}$ & $80.33^{\mathrm{a}}$ & $83.33^{\mathrm{a}}$ & $88.00^{\mathrm{a}}$ & 5.10 & $<0.05$ \\
\hline Meat content $(\mathrm{g})$ & 46.33 & 45.33 & 55.33 & 56.33 & 4.71 & 0.08 \\
\hline Gut content $(\mathrm{g})$ & $15.33^{\mathrm{b}}$ & $17.67^{\mathrm{ab}}$ & $23.67^{\mathrm{a}}$ & $23.67^{\mathrm{a}}$ & 2.22 & $<0.05$ \\
\hline Foot-length $(\mathrm{cm})$ & 6.67 & 7.50 & 7.50 & 7.70 & 0.34 & 0.07 \\
\hline Foot thickness $(\mathrm{cm})$ & 1.60 & 1.73 & 1.80 & 1.80 & 0.16 & 0.08 \\
\hline
\end{tabular}

Means with different superscripts in each row are significantly different $(\mathrm{p}<0.05)$.

\section{Conclusion}

The present study showed that it is safe to supplement African giant land snail diet with FLM up to $15 \%$. Low percentage mortality recorded in the study also confirms that MFL FLM is not toxic and can be tolerated by snails. FLM is a water weed growing wild and cost very little to add to snail feed. This could help also in cost saving of feed without compromising feed quality.

\section{References}

[1]. A.O.A.C. (1990) Association of Official Analytical Chemistry $15^{\text {th }}$ edition Washington D.C)

[2]. A.O.A.C. (1995): Association of official Analytical Chemists, Official Methods of Analysis, 13 edition Washington, D.C.

[3]. Ajayi, et al (1978): Observation on the Biology and Nutritive value of the African Giant Snail. Africa Wildlife. Pp.86-87.

[4]. Akinnusi, O. (1997): Snail farm: Low investment and high profit livestock, Echo Publishers, Lagos.

[5]. Akinnusi, O. (1998): Introduction to Snail and Snail Farming. Omega Science Publishing Jinuose House, Lagos, Nigeria.

[6]. Akinnusi, O. (2004): Introduction to Snail and Snail Farming. Second Edition, Published by Triolas Exquisite ventures, AbeokutaIbadan Road, Camp, Abeokuta, Nigeria.

[7]. Akintomide, T.O. (2004): Tropical Snail Farming.

[8]. Alikwe, P.C.N. (2011): Personal Communication.

[9]. Amusan, J.A. and Omidisi, M.O. (1999): Edible land Snail: A Technical Guide to Snail Farming in the Tropics. Variety Printer Ltd. Pg. 3.12.

[10]. Awah, A.A. (1992). Snail Farming in mature Rubber Plantation: I Studies on aspect of specialized Production techniques for farming architectin, Marginata: Snail Farming Research 4: 33-39.

[11]. Awesu, M.O. (1980): The Biology and Domestication of the African Giant and Snail Archachatina Maginat. A.M. Phil. Thesis Dept. of forestry resources Management: University of Ibadan. Ibadan-Nigeria.

[12]. Awesu, M.O. (1988): Observation on some aspect of reproduction of Archachatina (Swainson) in captivity in a culture pen, Snail Research 2:39-44.

[13]. Cobbinah, J.R. (1994) Snail Farming in West African: a practical guide. Technical centre for agricultural and ruralco-operation (CTA)Wageningen, The Netherlands.

[14]. Duncan, D.B. (1955): Multiple ranges and multiple f-test Biometric 11.225-226.

[15]. Ebenso, I.E and Okafor, N.M. (2002). Alternative diets for growing Archachatina Snails in Southern Nigeria: Tropical Science (England) 42 (3): 144-145.

[16]. Ebenso, I.E. (2002): Consumption and Sales of domesticated snails archachatina marginata in rural southern Nigeria. Tropical Science (England) 42 (4): 185-187.

[17]. Ebenso, I.E. (2003a): Mollusadal Effect of Neen (Azadirachfa Indian) Extracts on Edible Tropical Snails Pest management Science (England) Accepted - in Press.

[18]. Ebenso, I.E. (2003b): Nutritive Potential of White Snails Archachatina Marginata in Nigeria. Discovery and innovation (Kenya) Accepted in Press.

[19]. Elmslie, L.J. (1982): Snails and Snail Farming World Animal Keview (FAO) 41:20-26.

[20]. Fasakin, E.A. (1999): Nutrient Quality of Leaf Protein concentration produced from Water Fern (Azolla African Desv). Azolla African and Deckweed (Spirodel, Polyrrruzi L. Schleiden).

[21]. Hodasi, J.K.M. (1979): Life History studies of Achatina (Achatina) Achatina (Linne). Journal of Mollescan Studies Vol. 45 pp3 30 339.

[22]. Hodasi, J.K.M. (1984): Some observation on Edible Giant Land Snail of West Africa. World animal Review 52, $24-25$.

[23]. Hodasi, J.K.M. (1986): Effect of Different Types of Food onteh Growth of Archachatina. Proceeding of the $12^{\text {th }}$ International Malacological Congress, Vigo. Span, Edited by Guerra A. Rolace and Kochaf. Pp.488-489.

[24]. Imevbore, E.A. and Ademosum, A.A. (1988): The Nutritive value of the Africa Giant Land Snail Archachatina Marginafa. Journal of Animal Production Research (2) 76-87.

[25]. Ireland, M.P. 91991): The Effect of dietary Calcium on Growth, Shell, Thickness and Tissue distribution on the snail protecting fulcia. Comparative Biochemistry and physiology 98A (11:111-116).

[26]. Mannar, et al(2008): A Review on the Potential uses of Fern, Elhnobo Janical leaflet - Vol. 2008: ISS. 1, Article 33. Available at htt://opensiuc.lib.Sili.eda/eb//vol /2008/ISSI/33.

[27]. Mead, A.R. (1961), The Giant African Snail: A Problem in Economics Malacology, University of Chicago Press, Chicago Pp. 257.

[28]. Morton, J.E. (1967) Molluses physiological ecology. Molluses fourth Edition, Hutchinson, university library, London England.

[29]. Nisbef, R.N. (1974). The life of Archa idea in London, Procmalac, Soc Lond 41:1171.

[30]. Ogbeide, O.C. (1968) Traditional lizards of food, taboos and Preference in mid-west Nigeria. American Journal of Nutrition 27:213216.

[31]. Orisawayi, Y.A. (1996). Practical Guide to Snail Farming.

[32]. Plummer, J.M. (1975): Observation on the reproduction, growth and longevity of a laboratory colon of a Marginata. Proc. Malac Society, London. 
[33]. Segun, A.O. (1975): The Giant Land Snail Archachatina (Calachatina) Marginata (Swainson). Ethioe Publishing House Benin City, Nigeria.

[34]. Tamang. J.P. (1972): Studies on the Microflora of some tratiditonal fermented foods of the Darjeeling Hills and Sikkin Ph.D Thesis, NBU, Darjeeling, India, 224pp.

[35]. Tunde, F. (2006). Snail Bearing, Seminar Delivered at 3 community Road Okaka, Yaba- Lagoa.

[36]. Udo, E.J. and Fayemi, A.A.A (1975): The Effect on Oil Production of Soil on Germination, Growth and Nutrient uptake of Corn. Journal of Environmental quality 4(4): 537-540.

[37]. Wikipedia, the Free Encyclopaedia (2010): Aquatic Plant. En.Wikipedia.org/wiki/aquatic- Plant-cached-Similar.

[38]. Yoloye, L.V. (1988). Basic invertebrate Zoology, University of Ilorin Press Ilorin, Pp:318-318. 